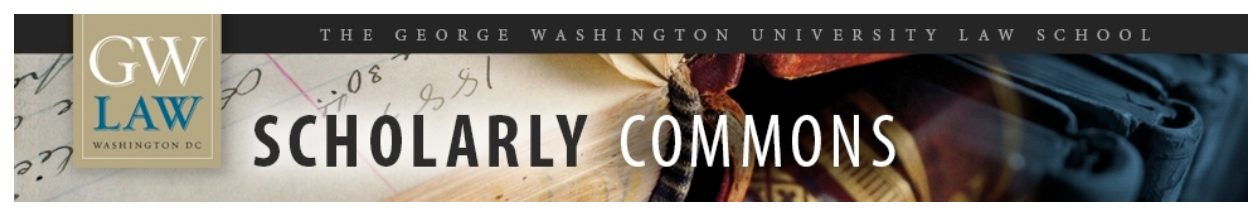

\title{
Human Rights and the Environment: Substantive Rights
}

Dinah L. Shelton

George Washington University Law School, dshelton@law.gwu.edu

Follow this and additional works at: https://scholarship.law.gwu.edu/faculty_publications

Part of the Law Commons

\section{Recommended Citation}

Dinah Shelton, Human Rights and the Environment: Substantive Rights, in RESEARCH HANDBOOK ON INTERNATIONAL ENVIRONMENTAL LAW (Malgosia Fitzmaurice, David M. Ong \& Panos Merkouris eds., 2011).

This Book Part is brought to you for free and open access by the Faculty Scholarship at Scholarly Commons. It has been accepted for inclusion in GW Law Faculty Publications \& Other Works by an authorized administrator of Scholarly Commons. For more information, please contact spagel@law.gwu.edu. 


\section{Research Handbook on International Environmental Law}

Edited by

Malgosia Fitzmaurice

Professor of Public International Law, Queen Mary, University of London, $U K$

David M. Ong

University of Essex, $U K$

Panos Merkouris

Queen Mary, University of London, UK

RESEARCH HANDBOOKS IN INTERNATIONAL LAW

\section{Edward Elgar}

Cheltenham, UK • Northampton, MA, USA 


\section{Human rights and the environment: substantive rights}

\section{Dinah Shelton}

\section{Introduction}

International attention to the links between human rights and environmental protection has expanded considerably in the past several decades. As early as the 1972 Stockholm Conference on the Human Environment, participating states recognized that environmental degradation hampers the enjoyment of internationally guaranteed human rights. In the Conference's concluding declaration, the participating states referred to the fundamental rights of freedom, equality and adequate conditions of life in an environment of a quality that permits a life of dignity and well-being. The three headings of freedom, equality and adequate conditions of life encompass recognized civil, political, economic and social rights. The UN General Assembly reaffirmed the linkage between human rights and environmental protection in resolution 45/94, stating that all individuals are entitled to live in an environment adequate for their health and well-being and calling for enhanced efforts to ensure a better and healthier environment.

During the three decades since the Stockholm Conference, law-makers in many countries have drafted constitutional and legislative provisions to add environmental rights, including the right to an environment of a specified quality, such as 'healthy', 'safe', 'secure', 'clean' or 'ecologically sound'. Two international treaties also directly guarantee a right to environmental quality (see infra). In addition to these direct substantive rights, environmental guarantees also emerge indirectly, because courts interpreting and enforcing other rights have recognized that violations of them may be the result of a degraded environment. International human rights tribunals, in particular, have come to view environmental protection as essential for the enjoyment of certain internationally guaranteed human rights, especially the rights to life, health, home life, and property. Environmental protection is thus deemed a prerequisite to the effort to secure the effective enjoyment of human rights.

Substantive guarantees to an environment of a quality that is compatible with health and well-being are separate from, although interdependent with, the procedural rights to information, participation and access to justice. The latter rights are matters of process, intended to ensure that decision-making takes place with informed input from those potentially affected by the decision and that these same persons have an avenue of redress for any harm that results. Substantive rights, in contrast, place certain limits on the outcome of the process, ensuring that the majority does not abuse its dominant position to discriminate or to cause environmental degradation at a level that infringes the enjoyment of human rights.

Apart from recognizing that human rights cannot be enjoyed in a degraded environment, there are several other reasons why those persons concerned with environmental protection may adopt a rights-based approach. First, human rights are maximum claims on society, elevating concern for the environment above a mere policy choice that may be modified or discarded at will. Rights are inherent attributes of human beings that must be respected in any well-ordered society. The moral weight this concept affords exercises an important compliance 
pull. Second, all legal systems establish a hierarchy of norms. Constitutional guarantees usually are at the apex and 'trump' any conflicting norm of lower value. Thus, recognizing a sound environment as a constitutional right ensures that its protection will be given precedence over other legal norms that are not constitutionally based. Third, at the international level, enforcement of human rights law is more developed than are the procedures of international environmental law. The availability of individual complaints procedures to denounce violations of human rights has given rise to extensive jurisprudence in which the specific obligations of states to protect and preserve the environment are detailed.

\section{Human rights treaties}

Most human rights treaties were drafted and adopted before environmental protection became a matter of international concern. There are thus few direct references to environmental rights in such instruments. Some provisions are relevant to this end, however, such as Article 7(b) of the International Covenant on Economic, Social and Cultural Rights (ICESCR, 16 December 1966), which guarantees the right to safe and healthy working conditions, and Article 10(3), which assures the right of children and young persons to be free from work harmful to their health. The right to health (ICESCR, Article 12) expressly calls on states parties to take steps for 'the improvement of all aspects of environmental and industrial hygiene' and 'the prevention, treatment and control of epidemic, endemic, occupational, and other diseases'.

The Convention on the Rights of the Child (CRC, 20 November 1989) refers to aspects of environmental protection in respect of the child's right to health. Article 24 provides that states parties shall take appropriate measures to combat disease and malnutrition 'through the provision of adequate nutritious foods and clean drinking water, taking into consideration the dangers and risks of environmental pollution' (Article 24(2)(c)). Information and education on hygiene and environmental sanitation are to be provided to all segments of society (Article $24(2)(e)$ ). In the context of the state periodic reporting procedure, the CRC Committee on the Rights of the Child has issued observations calling for better compliance with Article 24(2)(c). In its Concluding Observations on the state report submitted by Jordan, the CRC Committee recommended that Jordan 'take all appropriate measures, including through international cooperation, to prevent and combat the damaging effects of environmental pollution and contamination of water supplies on children and to strengthen procedures for inspection".

The CRC's Concluding Observations on South Africa also expressed the Committee's 'concern ... at the increase in environmental degradation, especially as regards air pollution' and 'recommend[ed] that the State Party increase its efforts to facilitate the implementation of sustainable development programmes to prevent environmental degradation, especially as regards air pollution'.1

ILO Convention No. 169 concerning Indigenous and Tribal Peoples in Independent Countries (27 June 1989) contains numerous provisions calling for protection of the lands, resources, and environment of indigenous peoples (for example, Articles 2, 6, 7, 15). Articles 4 and 7(4) call for the adoption of measures to safeguard, protect and preserve the environment of the peoples concerned, while Article 7(2) requires environmental and social impact studies be conducted of planned development activities in areas they inhabit. Part II of the Convention addresses land issues, including the rights of the peoples concerned to the natural resources pertaining to their lands (Article 15).

The United Nations has not approved any general normative instrument directly guaran- 
teeing substantive environmental rights, although the former UN Commission on Human Rights adopted several resolutions on related matters. Resolution 2005/60 of 20 April 2005, for example, entitled 'Human Rights and the Environment as Part of Sustainable Development', noted that environmental damage can have potentially negative effects on the enjoyment of human rights and on a healthy life and a healthy environment, and that protection of the environment and sustainable development can contribute to human well-being and potentially to the enjoyment of human rights. The resolution emphasized the needs of the most vulnerable members of society.

Two regional human rights treaties each directly guarantee a substantive right to environment. The African Charter on Human and Peoples' Rights (26 June 1981), Article 24, provides that 'All peoples shall have the right to a general satisfactory environment favorable to their development'. The Additional Protocol to the American Convention on Human Rights in the Area of Economic, Social and Cultural Rights (17 November 1988), Article 11, proclaims:

1. Everyone shall have the right to live in a healthy environment and to have access to basic public services.

2. The States Parties shall promote the protection, preservation and improvement of the environment.

The European Convention for the Protection of Human Rights and Fundamental Freedoms (4 November 1950) does not mention the environment, but cases nonetheless have been brought to the European Court of Human Rights for environmental harm. The substantive rights invoked have been the right to life (Article 2), the right to privacy and family life (Article 8 ), and the right to property. ${ }^{2}$ Most of the early decisions concerned Article 8 and held that environmental harm attributable to state action or inaction that has significant injurious effect on a person's home or private and family life constitutes a breach of Article 8(1). The harm may be excused under Article 8(2) if it results from an authorized activity of economic benefit to the community in general, as long as there is no disproportionate burden on any particular individual; that is, the measures must have a legitimate aim, be lawfully enacted, and be proportional. States enjoy a certain discretion or 'margin of appreciation' in determining the legitimacy of the aim pursued.

\section{Substantive environmental rights in national law}

More than 100 constitutions throughout the world guarantee a right to a clean and healthy environment, impose a duty on the state to prevent environmental harm, or call for protection of the environment or natural resources. Over half of the constitutions, including nearly all adopted since 1992 , explicitly recognize the right to a clean and healthy environment. ${ }^{3}$ Ninety-two constitutions impose a duty on the government to prevent harm to the environment. Examples include Angola (Article 24(1): 'All citizens shall have the right to live in a healthy and unpolluted environment'), Argentina (Article 41: 'All residents enjoy the right to a healthy, balanced environment which is fit for human development ...'), and Brazil (Article 225: 'Everyone has the right to an ecologically balanced environment, which is a public good for the people's use and is essential for a healthy life').

Constitutional environmental rights are increasingly being enforced by courts. In India, for example, a series of judgments between 1996 and 2000 responded to health concerns caused by industrial pollution in Delhi. ${ }^{4}$ In some instances, the courts issued orders to the companies 
to cease operations (see M.C. Mehta v. Union of India \& Others, 1996). The Indian Supreme Court has based its closure orders on the principle that health is of primary importance and that residents are suffering health problems due to pollution. South African courts also have deemed the right to environment to be justiciable. ${ }^{5}$ In Argentina, the right is deemed a subjective right entitling any person to initiate an action for environmental protection (Kattan, Alberto and Others v. National Government, 1983; Irazu Margarita v. Copetro SA, 1993). ${ }^{6}$ Colombia also recognizes the enforceability of the right to environment (Fundepublico $v$. Mayor of Bugalagrande and Others, 1991). ${ }^{7}$ In Costa Rica, one court stated that the rights to health and to the environment are necessary to ensure that the right to life is fully enjoyed (Presidente de la sociedad Marlene SA v. Municipalidad de Tibas, 1994).

Using a federal statutory provision, United States courts have heard complaints about environmental harm and human rights violations brought by injured parties in other countries. ${ }^{8}$ In 1993, residents of Ecuador and Peru brought actions alleging that a US-based multinational oil company contaminated lands and rivers, causing severe health consequences (Jota v. Texaco, 1998; Aguinda v. Texaco, 2000). Similarly, four Nigerians sued Royal Dutch Shell for its actions in Nigeria, including pollution of the air and water of the Ogoni region (Wiwa v. Royal Dutch Petroleum Co. and Shell Transport \& Trading Co. PLC, 2002). Another case was brought and settled concerning violations of the rights to life and health of local communities and environmental harm resulting from the construction of the Yadana gas pipeline in Burma (Doe v. Unocal Corp., 1999).

When national authorities do not respect constitutional or statutory environmental rights, the omission may put the government in breach of international human rights obligations. The judgment of the European Court of Human Rights in the case of Okyay and Others v. Turkey (App. no. 36220/97, judgment of 12 July 2005) is illustrative.

The applicants complained under Article 6 of the European Convention on Human Rights that their right to a fair hearing had been violated due to the refusal of Turkish administrative authorities to enforce judicial orders to halt the operations of three thermal-power plants in south-west Turkey. Relying on Article 56 of the Turkish Constitution ${ }^{9}$ and section 3(a) of the Environment Act, ${ }^{10}$ the applicants argued that it was their constitutional right to live in a healthy and balanced environment, and their duty to ensure the protection of the environment and to prevent environmental pollution.

Domestic courts had agreed with the applicants and enjoined operation of the power plants, noting that the plants had already caused pollution that was harmful to human health and the environment and that their continued operations could give rise to irreparable harm to members of the public. Nonetheless, the Council of Ministers, composed of the Prime Minister and other cabinet ministers, decided that the three thermal-power plants should continue to operate. Subsequently, the applicants filed criminal complaints with the offices of the Ankara Chief Public Prosecutor and public prosecutors in the jurisdictions in which the plants were situated. They unsuccessfully asked the prosecutors to institute criminal proceedings against the members of the Council of Ministers and other relevant administrative authorities for failure to execute the court decisions. Independently, nine civil judgments resulted from cases brought by farmers living in the vicinity of one thermal-power plant, who alleged that the quality and quantity of their olive and tobacco production had been adversely affected by the poisonous gas and ash emitted by the power plant and that they had therefore suffered pecuniary damage. They were awarded compensation.

The European Court examined the domestic law of Turkey, but also referred to Principle 
10 of the Rio Declaration and to Parliamentary Assembly Recommendation 1614 (2003) on Environment and Human Rights, in which the Assembly recommended that the governments of member states

(i) ensure appropriate protection of the life, health, family and private life, physical integrity and private property of persons in accordance with Articles 2, 3 and 8 of the European Convention on Human Rights and by Article 1 of its Additional Protocol, by also taking particular account of the need for environmental protection; and (ii) recognize a human right to a healthy, viable and decent environment which includes the objective obligation for states to protect the environment, in national laws, preferably at constitutional level ...

The Court noted that the applicants challenged the operation of the three thermal-power plants on account of the damage they had caused to the environment and the risks they posed for the life and health of the Aegean region's population, to which they belonged. While the applicants did not claim to have suffered any economic or other loss, they relied on their constitutional right to live in a healthy and balanced environment recognized in Turkish law. Given the constitutional guarantee, the Court was satisfied that the applicants could arguably claim that they were entitled under Turkish law to protection against damage to the environment caused by the power plants' hazardous activities. It followed that there existed a genuine and serious 'dispute' over a 'civil right', as required by the language of Convention Article 6(1). The European Court reiterated that the execution of a judgment given by a court is to be regarded as an integral part of the 'trial' because the right of access to a court would be rendered illusory if a contracting state's legal system allowed a final judicial decision or an interlocutory order to remain inoperative to the detriment of one party. The Court found the principle to be of even greater importance in the context of administrative proceedings concerning a dispute over a litigant's civil rights. The Turkish authorities' actions were tantamount to circumventing the judicial decisions. In the Court's opinion, such a situation adversely affected the principle of a state founded on the rule of law and the principle of legal certainty. Therefore, the national authorities' failure to comply in practice and within a reasonable time with the domestic judgments was a violation of Convention Article 6(1).

\section{The jurisprudence of international tribunals}

The failure of multilateral environmental agreements to create complaint procedures has led individuals and groups who have suffered harm due to environmental conditions to file their claims before international human rights tribunals. In addition, human rights treaty bodies have sometimes addressed the intersection of human rights and environmental protection in their interpretive statements, known as General Comments, and during their consideration of periodic state reports.

\section{The right to life}

The UN Human Rights Committee has rejected on procedural grounds most of the communications alleging violation of the right to life guaranteed by the International Covenant on Civil and Political Rights, without deciding the merits of the complaint. In the early case of EHP $v$. Canada, a group of Canadian citizens alleged that the storage of radioactive waste near their homes threatened the right to life of present and future generations. The Committee found that the case raised 'serious issues with regard to the obligation of States parties to protect human life', but declared the case inadmissible due to failure to exhaust local remedies (EHP $v$. 
Canada, 1990: 20; see also Kitok v. Sweden, 1987/88: 442). ${ }^{11}$ In Bordes and Temeharo v. France, petitioners asserted the risk of harm to life and health due to nuclear radiation caused by French nuclear testing in the South Pacific (Bordes and Temeharo v. France, 1996). The Committee found the case inadmissible on the ground that the claimants did not qualify as 'victims' of a violation, apparently because of the remoteness of the harm. Applicants attempted to place the burden of proof on the government, contending that the French authorities had been unable to show that the tests would not endanger the health or the environment of the people living in the South Pacific. The Committee held that the applicants had not substantiated their claim that the tests had violated or threatened violation of the rights invoked. Scientific uncertainty proved decisive.

Oneryildiz v. Turkey, decided by a Grand Chamber of the European Court of Human Rights on 30 November 2004, was the first environmental case involving loss of life in the European human rights system. The two applicants asserted that the national authorities were responsible for the deaths of their close relatives and for the destruction of their property due to a methane explosion at a municipal waste dump in an area of Istanbul. In addition to asserting a violation of the rights to life and to property, the applicants complained that the administrative proceedings conducted in their case were unfair and violated the European Convention on Human Rights, Article 6 . The waste disposal site had originally been selected when the area was uninhabited, but over time unplanned settlements appeared. In 1991, the district council appointed experts to determine whether the site met existing regulations. The resulting report, transmitted to local authorities, the governor and the Ministry of Health and Environment Office, alerted authorities to a number of dangers giving rise to a major health risk for nearby inhabitants, particularly those living in the slum areas. The experts found that the site exposed humans, animals and the environment to the spread of contagious diseases and the formation of sufficient methane to explode. The Environment Office urged local authorities to remedy the problems, but no action was taken. On 28 April 1993 a methane explosion occurred followed by a landslide that destroyed ten dwellings and killed 39 people. Two mayors were prosecuted, found guilty and initially sentenced to three months in prison, but the sentences were commuted and enforcement of minimal fines that had been imposed was suspended. The applicant won an administrative judgment but the compensation was never paid.

In its judgment, the Court recalled that the Convention's guarantee of the right to life imposes not only a negative obligation on state authorities to refrain from the arbitrary use of force, but also includes a positive obligation on states to take appropriate steps to safeguard the lives of those within their jurisdiction. This obligation extends to any activity, whether public or not, 'in which the right to life may be at stake, and a fortiori in the case of industrial activities which by their very nature are dangerous, such as the operation of waste-collection sites' (Oneryildiz v. Turkey, 2004: para. 71).

The primary duty on the state is to put in place a legislative and administrative framework designed to provide effective deterrence against threats to the right to life. The Court took particular note of the dangerousness of the activity in this case and indicated that when such activities are undertaken, the state must enact regulations governing their licensing, setting up, operation, security and supervision, and must make it compulsory for all those concerned to take practical measures to ensure the effective protection of citizens whose lives might be endangered by the inherent risks. The Court also held that the procedural dimension of the right to life includes the right to information about dangerous activities. 
The Court held that Turkey also violated its duties in the aftermath of the explosion. According to the Court, where lives are lost in circumstances potentially engaging the responsibility of the state, Article 2 requires 'an adequate response' so that any breaches are repressed and punished. The Court considered that the applicable principles in this case were to be found in decisions concerning the use of lethal force. The duty to conduct an official investigation arises not only because criminal liability may be in question, but because in the context of dangerous activities, public authorities 'are often the only entities to have sufficient relevant knowledge to identify and establish the complex phenomena that might have caused such incidents' (Oneryildiz v. Turkey, 2004: para. 93). Beyond the duty to investigate, the Court indicated that prosecution may be necessary:

Where it is established that the negligence attributable to State officials or bodies on that account goes beyond an error of judgment or carelessness, in that the authorities in question, fully realizing the likely consequences and disregarding the powers vested in them, failed to take measures that were necessary and sufficient to avert the risks inherent in a dangerous activity ..., the fact that those responsible for endangering life have not been charged with a criminal offence or prosecuted may amount to a violation of Article 2, irrespective of any other types of remedy which individuals may exercise on their own initiative ...; this is amply evidenced by developments in the relevant European standards.

Turkish authorities were found to have acted with exemplary promptness in investigating the circumstances of the accident and ensuing deaths, but the manner in which the Turkish criminal justice system operated did not ensure accountability or the effective implementation of domestic law, in particular the deterrent function of the criminal law. The Court awarded pecuniary and non-pecuniary damages, together with costs and expenses, to the applicant, as well as non-pecuniary damages to each of his two sons.

The Inter-American Commission on Human Rights also has addressed environmental conditions as these affect the rights to life and health. In Yanomami v. Brazil, the InterAmerican Commission established a link between environmental quality and the right to life in response to a petition brought on behalf of the Yanomani Indians. The petition alleged that the government violated the American Declaration of the Rights and Duties of Man by constructing a highway through Yanomani territory and authorizing exploitation of the territory's resources. These actions had generated the influx of non-indigenous who brought contagious diseases which remained untreated due to lack of medical care. The Commission found that the government had violated the Yanomani rights to life, liberty and personal security guaranteed by Article 1 of the Declaration, as well as the right of residence and movement (Article VIII) and the right to the preservation of health and wellbeing (Article XI).

\section{The right to health}

In filing periodic reports on their implementation of the International Covenant on Economic, Social and Cultural Rights, states parties sometimes report on environmental issues as they affect guaranteed rights, particularly the right to health. In 1986, Tunisia reported to the Committee on Economic, Social and Cultural Rights about measures taken to prevent degradation of natural resources, particularly erosion, and about measures to prevent contamination of food (E/1986/3/Add.9). Similarly, the Ukraine reported in 1995 on the environmental situation consequent to the explosion at Chernobyl. Committee members sometimes request 
specific information about environmental harm that threatens human health. Poland, for example, was asked to provide information in 1989 about measures to combat pollution, especially in Upper Silesia (E/1989/4/Add.12).

On 8 November 2000, the Committee on Economic, Social and Cultural Rights issued General Comment No. 14, entitled 'Substantive Issues Arising in the Implementation of the International Covenant on Economic, Social and Cultural Rights (Article 12)'. The Comment states in paragraph 4 that 'the right to health embraces a wide range of socio-economic factors that promote conditions in which people can lead a healthy life, and extends to the underlying determinates of health, such as ... a healthy environment'. General Comment No. 14 adds that '[a]ny person or group victim of a violation of the right to health should have access to effective judicial or other appropriate remedies at both national and international levels' and should be entitled to adequate reparation (General Comment No. 14, 2000: para. 59).

Environmental cases in the African regional system have sometimes invoked the right to health, protected by Article 16 of the African Charter. In Communications 25/89, 47/90, 56/91 and 100/93 (Zaire), the African Commission on Human and Peoples Rights held that failure by the government to provide basic services such as safe drinking water constituted a violation of the right to health. ${ }^{12}$

In published studies addressing the situation of human rights in three different member states of the Organization of American States, the Inter-American Commission on Human Rights devoted particular attention to the links between the environment and the right to health ('Report on the Situation of Human Rights in Ecuador', 1997 (hereinafter 'Report on Ecuador'); 'Report on the Situation of Human Rights in Brazil', 1997; 'Third Report on the Situation in Paraguay', 2001). In its report on Ecuador, the Commission responded to claims that oil exploitation activities were contaminating the water, air and soil, thereby causing the people of the region to become sick and to have a greatly increased risk of serious illness ('Report on Ecuador', 1997: v). ${ }^{13}$ After an on-site visit, the Commission found that both the government and inhabitants agreed that the environment was contaminated, with inhabitants exposed to toxic byproducts in their drinking and bathing water, in the air, and in the soil. Many suffered skin diseases, rashes, chronic infections, and gastrointestinal problems. In addition, they claimed that pollution of local waters contaminated fish and drove away wildlife, threatening food supplies. The Commission emphasized that

[t]he realization of the right to life, and to physical security and integrity is necessarily related to and in some ways dependent upon one's physical environment. Accordingly, where environmental contamination and degradation pose a persistent threat to human life and health, the foregoing rights are implicated. ('Report on Ecuador', 1997: 88)

Governments may be required to take positive measures to safeguard the rights to life and physical integrity, in particular to prevent the risk of severe environmental pollution that could threaten human life and health, or to respond when persons have suffered injury. The Commission expressly noted that development activities must take place under conditions of respect for the rights of affected individuals. Thus, while the right to development implies that each state may exploit its natural resources,

the absence of regulation, inappropriate regulation, or a lack of supervision in the application of extant norms may create serious problems with respect to the environment which translate into violations of human rights protected by the American Convention. ('Report on Ecuador', 1997: 89) 


\section{The Commission concluded that}

[c]onditions of severe environmental pollution, which may cause serious physical illness, impairment and suffering on the part of the local populace, are inconsistent with the right to be respected as a human being ... The quest to guard against environmental conditions which threaten human health requires that individuals have access to: information, participation in relevant decisionmaking processes, and judicial recourse. ('Report on Ecuador', 1997: 92-3)

\section{Right to adequate standard of living}

The Committee on Economic, Social and Cultural Rights has referred to environmental issues in its General Comment on the Right to Adequate Food (General Comment No. 12, 1999) ${ }^{14}$ and its General Comment on the Right to Adequate Housing. In the first, the Committee interpreted the phrase 'free from adverse substances' in Article 11 of the Covenant to mean that the state must adopt food safety and other protective measures to prevent contamination through 'bad environmental hygiene'. The General Comment on housing states that 'housing should not be built on polluted sites nor in proximity to pollution sources that threaten the right to health of the inhabitants' (General Comment No. 4, 1991: para. 5).

The Committee on Economic, Social and Cultural Rights also adopted, in November 2002, General Comment No. 15 on the right to water. ${ }^{15}$ The Committee, noting that water is a limited natural resource and a public good fundamental to life and health, called it a prerequisite for the realization of other human rights. It determined that the human right to water entitles everyone to sufficient, safe, acceptable, physically accessible and affordable water for personal and domestic uses. The Committee affirmed that while Covenant Article 11(1) on the right to an adequate standard of living does not specifically mention water, it guarantees a number of rights emanating from and indispensable for this right, including adequate food, clothing and housing. The use of the word 'including' was deemed to indicate that the list is not exhaustive. The right to water was also found to be inextricably related to the right to the highest attainable standard of health (Article 12(1)) and the right to life. Priority should be given to the water resources required to prevent starvation and disease.

General Comment No. 15 establishes that the right to water contains both freedoms and entitlements. Freedoms include the right to maintain access to existing necessary water supplies and the right to be free from interferences, such as arbitrary disconnections or contamination of water supplies. In contrast, entitlements include the right to a system of water supply and management that provides equality of opportunity for people to enjoy the right to water. States parties have a special obligation to provide those who do not have sufficient means with the necessary water and water facilities and to prevent any discrimination on internationally prohibited grounds in the provision of water and water services.

State obligations are divided into immediate obligations and those which states may realize progressively. States parties have immediate obligations to guarantee the exercise of the right to water without discrimination of any kind (Article 2(2)) and the obligation to take steps (Article 2(1)) to respect, to protect and to fulfil the right. Such steps must be deliberate, concrete and targeted towards the full realization of the right to water. There is a strong presumption that retrogressive measures are prohibited. The obligation to respect requires that states parties refrain from interfering directly or indirectly with the enjoyment of the right to water. The obligation to protect requires state parties to prevent individuals, groups, corporations and other third parties from interfering in any way with the enjoyment of the right to water. The obligation includes, inter alia, adopting the necessary and effective legislative and 
other measures to restrain third parties from denying equal access to adequate water, or from polluting and inequitably extracting water. States parties are obliged to fulfil (provide) the right when individuals or a group are unable, for reasons beyond their control, to realize that right themselves by the means at their disposal. The lengthy General Comment also discusses core obligations and the state acts and omissions that may be held to violate the Covenant's guaranteed right to water.

\section{Minority rights}

In a General Comment interpreting the guarantee in ICCPR Article 27 that members of minority groups have the right to enjoy their own culture, the UN Human Rights Committee has stated that the provision protects a

particular way of life associated with the use of land resources, especially in the case of indigenous peoples. That right may include such traditional activities as fishing or hunting and the right to live in reserves protected by law ... The protection of these rights is directed towards ensuring the survival and continued development of the cultural, religious and social identity of the minorities concerned, thus enriching the fabric of society as a whole. (General Comment No. 23: paras 7,9)

Communications alleging violations of Article 27, while having limited success on the merits, have nonetheless served to explain government obligations respecting environmental protection and the human rights of minority groups. In Ilmari Lansman et al. v. Finland, the Committee found that Article 27 was not violated by the extent of stone-quarrying permitted by Finland in traditional lands of the Sami (Ilmari Lansman et al. v. Finland, 1996). The Committee observed that a state may wish to encourage development or economic activity, but said that measures must be taken 'to ensure the effective participation of members of minority communities in decisions which affect them'. The Committee concluded that the amount of quarrying that had taken place did not constitute a denial of the applicants' right to culture and noted that the group was consulted and their views taken into account in the government's decision. Moreover, measures were taken to minimize the impact on reindeerherding activity and on the environment. ${ }^{16}$ The Committee's decision in Apirana Mahuika et al. v. New Zealand, 1993 (views issued on 16 November 2000) similarly emphasized that

the acceptability of measures that affect or interfere with the culturally significant economic activities of a minority depends on whether the members of the minority in question have had the opportunity to participate in the decision-making process in relation to these measures and whether they will continue to benefit from their traditional economy.

The complicated process of consultation undertaken by the government was held to comply with this requirement, because the government paid special attention to the cultural and religious significance of fishing for the Maori.

The Inter-American Court of Human Rights judgment in Awas Tingni Mayagna (Sumo) Indigenous Community v. Nicaragua emerged from a complaint about government-sponsored logging of timber on indigenous forest lands in Nicaragua. The indigenous community alleged violations of the rights to cultural integrity, religion, equal protection and participation in government. The 31 August 2001 judgment declared that the state violated the right to judicial protection (Article 25 of the American Convention) and the right to property (Article 21 of the Convention). It unanimously held that the state must adopt domestic laws, administrative regulations and other necessary means to create effective surveying, demar- 
cating and title mechanisms for the properties of the indigenous communities, in accordance with customary law and indigenous values, uses and customs. Pending demarcation of the indigenous lands, the state must abstain from realizing acts or allowing the realization of acts by its agents or third parties that could affect the existence, value, use or enjoyment of those properties located in the Awas Tingni lands. The Court also awarded reparations. ${ }^{17}$

The Inter-American Human Rights Commission's 'Report on Brazil' discussed problems of environmental destruction leading to severe consequences violating the rights to health and culture. Indigenous cultural and physical integrity were said to be under constant threat and attack from invading prospectors and the environmental pollution they created. State protection against the invasions was called 'irregular and feeble', leading to constant danger and environmental deterioration. Similarly, in its 2001 country study on Paraguay, the InterAmerican Commission recommended that the government adopt strategies to fight poverty, including protecting environmental resources and the social capital of poor communities, noting that these are resources people can draw upon to escape poverty. The Commission pointed to deforestation, water pollution and flooding of traditional lands by hydroelectric projects, recommending that the state adopt the necessary measures to protect indigenous communities from environmental degradation, with special emphasis on protecting the forests and waters, 'which are fundamental for their health and survival as communities'.

\section{The right to a specific kind of environment}

The African Commission on Human and Peoples' Rights held, in Communication 155/96 (Social and Economic Rights Action Center/Center for Economic and Social Rights $v$. Nigeria, 2002), ${ }^{18}$ that the right to environment, among other rights, was violated by Nigeria. The Commission coupled the claimed violations of the rights to health (Article 16) and to a general satisfactory environment (Article 24), recognizing that a "clean and safe environment ... is closely linked to economic and social rights in so far as the environment affects the quality of life and safety of the individual' (para. 51) ${ }^{19}$ It found that the right to a general satisfactory environment 'imposes clear obligations upon a government', requiring the state 'to take reasonable and other measures to prevent pollution and ecological degradation, to promote conservation, and to secure an ecologically sustainable development and use of natural resources' (para. 52).

The Commission called on the Nigerian government to stop all attacks on Ogoni communities; to allow independent investigators free access to the territory to conduct an investigation into the human rights violations that occurred; to prosecute those responsible for any such violations; to ensure adequate compensation for victims of violations, including a comprehensive clean-up of lands and rivers damaged by oil operations; to ensure that appropriate environmental and social assessments are prepared for future oil operations and that effective and independent oversight bodies exist for the petroleum industry; and, for communities likely to be affected by oil operations, to provide information on health and environmental risks, and meaningful access to regulatory and decision-making bodies.

\section{The right to privacy and home life}

The first major decision of the European Court of Human Rights on environmental harm as a breach of the right to respect for privacy and the home was Lopez-Ostrav. Spain. The applicant and her daughter suffered serious health problems from the fumes of a tannery waste treatment plant which operated alongside the apartment building where they lived. The plant 
opened without a required licence and without having followed the procedure for obtaining one. The applicant was eventually forced to move due to the pollution levels. The Court noted that severe environmental pollution may affect individuals' well-being and prevent them from enjoying their homes in such a way as to affect their private and family life. It found that the determination of whether this violation had occurred should be tested by striking a fair balance between the interest of the town's economic well-being and the applicant's effective enjoyment of her right to respect for her home and her private and family life. The Court found that the state exceeded its 'margin of appreciation' and awarded compensation.

In Anna Maria Guerra and 39 others against Italy, the applicants complained of pollution resulting from operation of a chemical factory situated near their town; the risk of major accidents at the plant; and the absence of regulation by the public authorities. A Grand Chamber of the European Court of Human Rights affirmed that there had been a violation of Article 8, noting that the individuals waited throughout the operation of fertilizer production at the company for essential information 'that would have enabled them to assess the risks they and their families might run if they continued to live at Manfredonia, a town particularly exposed to danger in the event of an accident at the factory'. The Court declined to consider whether the right to life guaranteed by Article 2 had been violated, considering it unnecessary in light of its decision on Article 8 , despite the fact that deaths from cancer had occurred in the factory and this would have a clear bearing on damages.

Most of the European environmental cases invoking the protection of privacy and home life contained in Convention Article 8 involve noise pollution. In Arrondelle v. United Kingdom, the applicant complained of noise from Gatwick Airport and a nearby motorway. The application was declared admissible and eventually settled. ${ }^{20}$ The settlement left unresolved numerous issues, some of which were addressed by the Court in Powell \& Raynor v. United Kingdom. The Court found that aircraft noise from Heathrow Airport constituted a violation of Article 8, but was justified under Article 8(2) as 'necessary in a democratic society' for the economic well-being of the country. Noise was acceptable under the principle of proportionality, if it did not 'create an unreasonable burden for the person concerned', a test that could be met by the state if the individual had 'the possibility of moving elsewhere without substantial difficulties and losses'. ${ }^{21}$

The European Court of Human Rights revisited the question of noise pollution from Heathrow airport in Hatton and Others v. The United Kingdom. A Grand Chamber decision on 8 July 2003 found that the noise from increased flights at Heathrow airport between 4 a.m. and 6 a.m. did not violate the rights of the applicants to respect for their home and family life guaranteed by Article 8 . The Grand Chamber reiterated that 'where an individual is directly and seriously affected by noise or other pollution, an issue may arise under Article 8' (para. 96). In such cases, the Court will assess the government's actions on the substantive merits and scrutinize the decision-making process to ensure that due weight has been accorded to the interests of the individual (para. 99). The Court indicated that some weight must be given to the compatibility of the state's actions or inactions with domestic law ${ }^{22}$ but decided it would not be appropriate for the Court to adopt a special approach in this respect by reference to a special status of environmental human rights (para. 122). Applying its 'fair balance test' with deference to the government, the Court assessed the economic contribution of the flights and the harm to the individuals. It noted as an additional significant factor that the $2-3$ per cent of the population specially affected could "if they choose, move elsewhere without financial loss' (para. 127). ${ }^{23}$ On the procedural side, the Court agreed that the state must undertake 
appropriate investigations and studies in order to allow officials to strike a fair balance between the various conflicting interests, ${ }^{24}$ but this does not require 'comprehensive and measurable data ... in relation to each and every aspect of the matter to be decided' (para. 128). Looking at the studies done, the Court found that the government did not exceed its margin of appreciation in striking a balance and following the procedures it did to allow more night flights at Heathrow. Thus there was no violation of Article 8.

The applicant in Moreno Gomez v. Spain (judgment of 16 November 2004) succeeded in a claim that noise pollution from 127 bars, pubs and discotheques near his home violated Article 8. The Court again examined whether a 'fair balance' had been struck between the competing interests of the individual and the community as a whole in respect of the state's failure to take action to put a stop to third-party breaches of the right. The Court unanimously held that the noise levels were such as to amount to a breach of the rights protected by Article 8 . The fact that the city council did not enforce its enacted noise abatement measures was seen as contributing to the repeated flouting of the rules which it had established. The applicant was awarded the entire claim of damages as well as costs and expenses.

The case of Fadeyeva v. Russia, 2005 was the first to address 'ordinary' industrial pollution in one of the former Communist states of Eastern Europe. The applicant alleged that the operation of a steel-plant in close proximity to her home endangered her health and wellbeing in violation of Article 8 of the Convention. From 1995, the applicant, her family and other residents of the same apartment block sought resettlement outside the zone. Russian courts recognized that the applicant had the right in domestic law to be resettled, but issued no specific order to resettle the applicant. In August 1999, the municipality placed the applicant on the general waiting list for new housing. She was number 6820 . The applicant claimed that the concentration of certain toxic substances in the air near her home constantly exceeded the safe levels established by Russian legislation. Medical reports confirmed that the applicant suffered from various neurological disorders.

The Court summarized its earlier jurisprudence, noting that Article 8 is not violated every time that environmental deterioration occurs: for example, no right to nature preservation is as such included among the rights and freedoms guaranteed by the Convention (Kyrtatos $v$. Greece, 2003). Thus, in order to raise an issue under Article 8, the interference must directly affect the applicant's home, family or private life. Moreover, the adverse effects of environmental pollution must attain a certain minimum level if they are to fall within the scope of Article 8 . The assessment of that minimum is relative and depends on all the circumstances of the case, such as the intensity and duration of the nuisance, its physical or mental effects. The general environmental context should also be taken into account. There would be no arguable claim under Article 8 if the detriment complained of was negligible in comparison to the environmental hazards inherent in life in every modern city.

On the facts of this case, the Court found that the state authorized the operation of a polluting enterprise in the middle of a densely populated town. Since the toxic emissions from this enterprise exceeded the safe limits established by the domestic legislation and might endanger the health of those living nearby, the state established that a certain territory around the plant should be free of any dwelling. However, these measures were not implemented in practice. Although the situation around the plant called for a special treatment of those living within the zone, the state did not offer the applicant any effective solution to help her move from the dangerous area. Furthermore, although the polluting enterprise at issue operated in breach of domestic environmental standards, the state failed to design or apply effective 
measures which would take into account the interests of the local population affected by the pollution, or which would be capable of reducing the industrial pollution to acceptable levels. Thus, despite the wide margin of appreciation left to the respondent state, the Court held that it failed to strike a fair balance between the interests of the community and the applicant's effective enjoyment of her right to respect for her home and her private life, and accordingly there was a violation of Article 8. As regards future measures to be adopted by the government in order to comply with the Court's finding of a violation, the resettlement of the applicant in an ecologically safe area would be only one of many possible solutions. The government's obligation was to take appropriate measures to remedy the applicant's individual situation.

\section{Conclusion}

Nearly all global and regional human rights bodies have considered the link between environmental degradation and internationally guaranteed human rights, including the right to health. In most instances, the complaints brought have not been based upon a specific right to a safe and environmentally sound environment, but rather upon rights to life, property, health, information, and family and home life. Underlying the complaints, however, are instances of pollution, deforestation, water pollution, and other types of environmental harm. The emphasis on rights encourages an integration of democratic values and promotion of the rule of law into broad-based structures of governance. In addition, the existence of international petition procedures allows those harmed to bring international pressure to bear when governments lack the will to prevent or halt severe pollution that threatens human health and well-being. In many instances, petitioners have been afforded redress and governments have taken measures to remedy the violation. Sometimes the problem is the result of a combination of governmental lack of capacity and lack of political will. Pollution may be caused by powerful enterprises whose business and investment are important to the state or the state may have inadequate monitoring systems to ensure air or water quality. Even in these instances, petition procedures can help to identify problems and encourage a dialogue to resolve them, including by the provision of technical assistance.

The jurisprudence of human rights bodies generally has been consistent in balancing the government's desire for economic development with consideration of the environmental impacts of projects and activities on individuals and groups. Several factors weigh in the balance in any finding that a government has failed to respect the human rights of the applicants. One important factor is the rule of law: that is, whether or not the government has complied with its own laws and regulations on environmental protection. Whatever the level of protection the state has chosen and enacted, it must obey and enforce the law and a failure to do so denies the legitimate expectations of those affected, generally resulting in a finding that their rights have been violated. A second factor is the seriousness of the harm; where there are severe health consequences, the applicant is more likely to prevail despite economic benefits from the activity in question. This issue is usually considered as a question of the 'proportionality' of the measures taken by the state. If the applicants are part of a group which has borne a particularly heavy impact, this is likely to be perceived as 'disproportionate', without necessarily being labelled as discriminatory. Where the harm is so extreme that life has been lost, procedural duties arise to investigate and where appropriate prosecute and punish those involved. The tribunals will also consider whether or not the state exercised due diligence to prevent harm from hazardous activities, including adopting a legislative and 
regulatory framework designed to effectively deter negligence in the conduct of such activities. In sum, each case is taken on its facts in determining whether or not the state wrongly balanced the needs of the community as a whole with the consequences to the affected group.

Given the extensive treaty provisions and case law that use existing human rights, it may be asked whether or not a recognized and explicit right to a healthy, safe and environmentally sound environment adds to the existing protections and furthers the international values represented by environmental law and human rights. The primary argument in favour of such a right is that it elevates the entire spectrum of environmental issues to become a fundamental value of society, on a level equal to other rights and superior to ordinary legislation. In the absence of guaranteed environmental rights, constitutionally protected property rights may be given automatic priority instead of being balanced against health and environmental concerns. Other rights may similarly be invoked to strike down environmental and health measures that are not themselves rights-based.

Even where there is a guaranteed right to environment, it still must be balanced against other rights should there be a conflict. In a few instances, a specific priority may be established by law. The Constitution of Ecuador, Article 19, provides for example 'the right to live in an environment free from contamination'. The Constitution invests the state with responsibility for ensuring the enjoyment of this right and 'for establishing by law such restrictions on other rights and freedoms as are necessary to protect the environment'. Other states may reconcile conflicts through other balances, but including the right makes it possible to do so.

On a more theoretical level, human rights exist to promote and protect human well-being, to allow the full development of each person and the maximization of the person's goals and interests, individually and in community with others. This cannot occur without state protection of a safe environmental milieu, that is, air, water and soil. Pollution destroys health and thus not only destroys the environment, but infringes human rights as well.

\section{Notes}

1. Also relevant are the Concluding Observations on Kyrgyzstan, 2000 and the Concluding Observations on Grenada, 2000.

2. Other cases concern procedural rights, such as the right to information and the right to a hearing, which are outside the scope of this chapter. Article 8(1) of the European Convention on Human Rights and Fundamental Freedoms provides that 'everyone has the right to respect for his private and family life, his home and his correspondence'. Paragraph 2 provides:

There shall be no interference by a public authority with the exercise of this right except such as is in accordance with the law and is necessary in a democratic society in the interests of national security, public safety or the economic well-being of the country, for the prevention of disorder or crime, for the protection of health and morals, or for the protection of the rights and freedoms of others.

The right to property is contained in Article 1 of Protocol 1. It ensures that 'every natural or legal person is entitled to the peaceful enjoyment of his possessions'. Pollution or other environmental harm may result in a breach of Article 1 of Protocol 1, but only where such harm results in a substantial reduction in the value of the property and that reduction is not compensated by the state. In one case, the former European Commission on Human Rights stated that the right to peaceful enjoyment of possessions 'does not, in principle, guarantee the right to the peaceful enjoyment of possessions in a pleasant environment' (Rayner v. United Kingdom, 1986: 14).

3. Angola, Argentina, Azerbaijan, Belarus, Belgium, Benin, Brazil, Bulgaria, Burkina Faso, Cameroon, Cape Verde, Chad, Chechnya, Chile, China, Colombia, Congo, Costa Rica, Croatia, Cuba, Ecuador, El Salvador, Equatorial Guinea, Eritrea (draft), Finland, Georgia, Germany, Ghana, Greece, Guatemala, Guyana, Haiti, Honduras, Hungary, India, Iran, Kazakhstan, Kuwait, Laos, Latvia, Lithuania, Macedonia, Madagascar, Malawi, Mali, Malta, Mexico, Micronesia, Mongolia, Mozambique, Namibia, Nepal, Netherlands, Nicaragua, Niger, Palau, Panama, Papua New Guinea, Paraguay, Peru, Philippines, Poland, Portugal, Romania, Russia, 
São Tomé and Principe, Saudi Arabia, Seychelles, Slovakia, Slovenia, South Africa, South Korea, Spain, Sri Lanka, Suriname, Switzerland, Taiwan, Tajikistan, Tanzania, Thailand, Togo, Turkey, Turkmenistan, Uganda, Ukraine, Uzbekistan, Venezuela, Vietnam, Yugoslavia, Zambia.

4. As early as 1991, the Supreme Court interpreted the right to life guaranteed by Article 21 of the Constitution to include the right to a wholesome environment (Charan Lal Sahu v. Union of India, 1991). In a subsequent case, the Court observed that the 'right to life guaranteed by article 21 includes the right of enjoyment of pollution-free water and air for full enjoyment of life' (Subhash Kumar v. State of Bihar, 1991).

5. Section 24 of the South Africa Constitution provides:

Everyone has the right -

(a) to an environment that is not harmful to their health or well-being; and

(b) to have the environment protected, for the benefit of present and future generations, through reasonable legislative and other measures that -

(i) prevent pollution and ecological degradation;

(ii) promote conservation; and secure ecologically sustainable development and use of natural resources while promoting justifiable economic and social development.

On the enforceability of the constitutional rights, see Government of the Republic of South Africa v. Grootboom and Others, 2000.

6. Accessible at www.eldial.com.

The right to live in a healthy and balanced environment is a fundamental attribute of people. Any aggression to the environment ends up becoming a threat to life itself and to the psychological and physical integrity of the person.

7. 'It should be recognized that a healthy environment is a sina qua non condition for life itself and that no right could be exercised in a deeply altered environment.'

8. Jurisdiction over the matters are based on the federal Alien Tort Claims Act, 1789.

9. Article 56 of the Constitution provides:

Everyone has the right to live in a healthy, balanced environment. It shall be the duty of the State and the citizens to improve and preserve the environment and to prevent environmental pollution. ... The State shall perform this task by utilising and supervising health and social welfare institutions in both the public and private sectors....

10. The relevant provisions of the Environment Act, 1983 read as follows:

\section{Section 3:}

The general principles governing environmental protection and the prevention of environmental pollution shall be as follows:

a) Protecting the environment and preventing environmental pollution are the duty of individuals and legal entities as well as of all citizens, and they are required to comply with the measures to be taken and the principles laid down in reference to these matters...

11. The Swedish Reindeer Husbandry Act, 1971 was held not to violate the rights of an individual Sami as it was a reasonable and objective measure necessary for the continued viability and welfare of the minority as a whole.

12. The finding followed the consolidation of four communications asserting torture, killings, arbitrary detention, unfair trials, restrictions on the right to association and peaceful assembly, suppression of freedom of the press, denial of the right to education and the right to health. In regard to the latter, the Commission said:

Article 16 of the African Charter states that every individual shall have the right to enjoy the best attainable state of physical and mental health, and that States Parties should take the necessary measures to protect the health of their people. The failure of the Government to provide basic services such as safe drinking water and electricity and the shortage of medicine as alleged in communication $100 / 93$ constitutes a violation of Article 16. (AHG/207(XXXII), Annex VIII: 8)

13. The Commission first became aware of problems in this region of the country when a petition was filed on behalf of the indigenous Huaorani people in 1990. The Commission decided that the situation was not restricted to the Huaorani and thus should be treated within the framework of the general country report. 
14. The Covenants as well as other UN human rights treaties authorize each treaty body to issue General Comments, which constitute authoritative legal interpretations of the rights and obligations contained in the treaty.

15. Incorporated in Articles 11 and 12 of the ICESCR. The Committee had previously recognized that Article 11 contains a right to water in its General Comment No. 6.

16. Other cases involving Sami reindeer breeders include: O.S. et al. v. Finland, 1994; Jouni E. Lansmann et al. $v$. Finland, 1996).

17. Other indigenous land and resource rights cases include Sarayaku Indigenous Community v. Ecuador (Provisional Measures), 2004; Yakye Axa Indigenous Community v. Paraguay, 2005; Moiwana Community v. Suriname, 2005. At the Inter-American Commission, see Maya Indigenous Community of the Toledo District v. Belize, 2003 and the friendly settlement Enxet Lomexay and Kayleyphapopyet (Riachito) Indigenous Community v. Paraguay, 1999.

18. Accessible at http://www.umn.edu/humanrts/africa/comcases/allcases.html (hereinafter Decision).

19. Citing General Comment No. 14: The Right to the Highest Attainable Standard of Health.

20. A similar case was also resolved by friendly settlement; see Baggs v. United Kingdom, 1985.

21. Contrast the Vearncombe case, where the Commission found that the level and frequency of the noise did not reach the point where a violation of Article 8 could be made out and therefore the application was inadmissible (Vearncombe et al. v. United Kingdom and Federal Republic of Germany, I989).

22. The Grand Chamber notes that the Hatton case is unlike either Lopez Ostra or Maria Guerra, discussed below, because in the latter two cases the government's actions were irregular or incompatible with domestic law or procedures (para. 120).

23. As several applicants in the case had moved away from Heathrow by the time the Court heard the case, the record may have included information on the economic impact of the moves.

24. The dissent points out that the report on the economic well-being of the country were prepared for the government by the aviation industry and no attempt was made to assess the impact of the aircraft noise on the applicant's sleep.

\section{References}

Alfredson, G. and Ovsiouk, A. (1991), 'Human Rights and the Environment', Nordic Journal of International Law 60(1-2), 19-27.

Boyle, A. and Anderson, M. (1996), Human Rights Approaches to Environmental Protection, Oxford: Clarendon Press.

Cullet, P. (1995), 'Definition of an Environmental Right in a Human Rights Context', Netherlands Quarterly of Human Rights 13(1), 25-40.

Dejeant-Pons, M. (1993), 'The Right to Environment in Regional Human Rights Systems', in P. Mahoney and K. Mahoney (eds), Human Rights in the Twenty-first Century, Dordrecht: Martinus Nijhoff, 595-614.

Dejeant-Pons, M. and Pallemaerts, M. (2002), Droits de l'Homme et Environnement, Strasbourg: Conseil de l'Europe.

Desgagne, R. (1995), 'Integrating Environmental Values into the European Convention on Human Rights', AJIL $89(2), 263-94$.

Eaton, J. (1997), "The Nigerian Tragedy, Environmental Regulation of Transnational Corporations and the Human Right to a Healthy Environment', Boston University International Law Journal 15(1), 261-307.

Handl, G. (1992), 'Human Rights and Protection of the Environment: A Mildly "Revisionist" View', in A. Cancado Trindade (ed.), Human Rights, Sustainable Development and the Environment, San José, Costa Rica: Instituto Interamericano de Derechos Humanos, 117-42.

Hitchcock, R.K. (1994), 'International Human Rights, the Environment, and Indigenous Peoples', Colorado Journal of International Environmental Law and Policy 5(1), 1-22.

Kane, M.J. (1993), 'Promoting Political Rights to Protect the Environment', Yale Joumal of International Law 18, $389-411$.

Kiss, A. (1990), 'Le Droit à la Conservation de l'Environnement', Revue Universelle des Droits de l'Homme 2(12), 445-8.

McClymonds, J.T. (1992), 'The Human Right to a Healthy Environment: An International Legal Perspective', New York Law School Law Review 37(4), 583-633.

Popovic, N. (1996), 'In Pursuit of Environmental Human Rights: Commentary on the Draft Declaration of Principles on Human Rights and the Environment', Columbia Human Rights Law Review 27(3), 487-603.

Shelton, D. (1994), 'What Happened in Rio to Human Rights?' YBIEL 4, 75-93.

Shelton, D. (2001), 'Environmental Rights', in P. Alston (ed.), People's Rights, Oxford: OUP, 185-258.

Shutkin, W.A. (1991), 'International Human Rights Law and the Earth: The Protection of Indigenous Peoples and the Environment', Vanderbilt Journal of International Law 31(3), 479-511.

Swepston, L. (1990), 'A New Step in the International Law on Indigenous and Tribal Peoples: ILO Convention 169 of 1989', Oklahoma City University Law Review 15, 677-714. 
Symonides, J. (1990), 'The Human Right to a Clean, Balanced and Protected Environment', in T. Tonchia (ed.), Diriti dell'uomo e ambiente la partecipazione dei cittadini alle decisioni sulla tuttela dell'ambiente, Padua: CEDAM, 239 et seq.

Thorme, M. (1991), 'Establishing Environment as a Human Right', Denver Journal of International Law and Policy 19(2), 301-42.

van Dyke, J. (1993), 'A Proposal to Introduce the Right to a Healthy Environment into the European Convention Regime', Vanderbilt Environmental Law Journal 13, 323 et seq.

\section{Cases}

Aguinda v. Texaco, 2000 WL 122143 (31 January 2000).

Arrondelle v. United Kingdom (1980), DR 19, 186.

Arrondelle v. United Kingdom (1982), DR 26, 5.

Baggs v. United Kingdom (1985), DR 44, 13.

Baggs v. United Kingdom (1987), DR 52, 29.

Charan Lal Sahu v. Union of India (1990), AIR 1990 SC 1480.

Communication No. 155/96, Social and Economic Rights Action Center/Center for Economic and Social Rights v. Nigeria (2002), African Commission on Human and People's Rights, UN Doc. ACHPR/COMM/A044/1.

Communication No. 197/1985, Kitok v. Sweden (1988), Official Records of the Human Rights Committee 1987/88 2, 442, UN Doc. CCPR/7/Add.l.

Communication No. 431/1990, O.S. et al. v. Finland (1994).

Communication No. 511/1992, Ilmari Lansman et al. v. Finland (1996), UN Doc. CCPR/C/57/1.

Communication No. 547/1992, Apirana Mahuika et al. v. New Zealand (2000), UN Doc. CCPR/C/70/D/547/1993.

Communication No. 645/1995, Bordes and Temeharo v. France (1996), UN Doc, CCPR/C/57/D/645/1995.

Communication No, 67/1980, EHP v. Canada (1990), 2 Selected Decisions of the Human Rights Committee 2, 20.

Communication No. 671/1995, Jouni E. Lansmann et al. v. Finland (1996), CCPR/C/58/D/671/1995.

Doe v. Unocal Corp. 67 F. Supp. 2d 1140 (CD Cal. 1999).

Enxet Lomexay and Kayleyphapopyet (Riachito) Indigenous Community v. Paraguay, IACmHR, Rep. 90/99, Case 11.713.

Fadayeva v. Russia, ECtHR, App. No. 55723/00, Judgment of 9 June 2005.

Fundepublico v. Mayor of Bugalagrande and Others (1991), Juzgado Primero superior, Interlocutorio No. 032, Tulua, 19 December 1991.

Government of the Republic of South Africa v. Grootboom and Others (2000), BCLR 11, 169 (CC).

Guerra and Others v. Italy (1998), EHRR 26, 357.

Hatton v. UK (2003), EHRR 37, 28.

Irazu Margarita v. Copetro SA (1993), Camara Civil y Comercial de la Plata, Ruling of 10 May. 1993, accessible at: www.eldial.com.

Jota v. Texaco, Ind., 157 F. 3d 153 (2nd Cir., 1998).

Kattan, Alberto and Others v. National Government (1983), Juzgado Nacional de la Instancia en lo Contenciosoadministrativo Federal No. 2, Ruling of 10 May 1983, La Ley 1983-D, 576.

Kyrtatos v. Greece (2003), EHRR 36, 242.

Lopez-Ostra v. Spain (1994), EHRR 20, 277.

M.C. Mehta v. Union of India \& Others (1996), SCC 8, 462.

Maya Indigenous Community of the Toledo District v. Betize, IACmHR, Rep. 96/03, Comm. 12.053.

Mayagna (Sumo) Awas Tingni Conimunity v. Nicaragua (2001), IACtHR (Ser. C) No. 79.

Moiwana Community v Suriname (2005), IACtHR (Ser. C) No.124.

Okyay and Others v. Turkey, ECtHR, App. No. 36220/97, Judgment of 12 July 2005.

Oneryildiz v. Turkey (2004), EHRR 41, 20.

Powell and Rayner v. United Kingdom (1990), EHRR 12, 335. Presidente de la sociedad Marlene SA v. Municipalidad de Tibas, Sala Constitucional de la corte Supreme de justi-
cia. Decision No. 6918/94 of 25 November 1994 .

Rayner v. United Kingdom (1986), DR 47, 5.

Sarayaku Indigenous Community v. Ecuador (Provisional Measures) (2004), IACtHR (Ser. E).

Subhash Kumar v. State of Bihar (1991), AIR 1991 SC 420; SCC 1, 598.

Vearncombe et al. v. United Kingdom and Federal Republic of Germany (1989), DR 59, 186.

Wiwa v. Royal Dutch Petroleum Co and Shell Transport \& Tracling Co. PLC No. 96 CKV 8386 (KMW) SDNY, 28 February 2002, 2001 US Dist. LEXIS 3293.

Yakye Axa Indigenous Community v. Paraguay (2005), IACtHR (Ser, C) No, 125.

Yanomami v. Brazil (1985), IACtHR, Case 7615, Report No. 12/85, OAS/Ser.L/V/I.66, doc.10 rev.1. 
Treaties and documents

Alien Tort Claims Act (1789), USC 28, 1350.

Environment Act (1983), Law No. 2872, Official Gazette 11 August 1983.

IACmHR (1997), 'Report on the Situation of Human Rights in Brazil', OEA/Ser.L/V/II.97, doc.29, rev.1.

IACmHR (1997), 'Report on the Situation of Human Rights in Ecuador', OEA/Ser.L/V/II.96, doc.10, rev.1.

IACmHR (2001), 'Third Report on the Situation in Paraguay', OEA/Ser.L/V/II.1 10, Doc.52.

International Covenant on Civil and Political Rights (1966), UNTS 999, 171.

International Covenant on Economic, Social and Cultural Rights (1976), UNTS 993, 3.

Pan American Union (1948), 'Final Act of the Ninth Conference of Amęrican States', Res. XXX, reprinted in OAS (1996), Basic Documents Pertaining to Human Rights in the Inter-American System, Washington, DC: OAS.

UN Committee on the Rights of the Child (2000), 'Concluding Observations on Grenada', UN Doc. CRC/C/15/Add.121.

UN Committee on the Rights of the Child (2000), 'Concluding Observations on Jordan', UN Doc. CRC/C/15/Add.125.

UN Committee on the Rights of the Child (2000), 'Concluding Observations on Kyrgyzstan', UN Doc. CRC/C/15/Add.127.

UN Committee on the Rights of the Child (2000), 'Concluding Observations on South Africa', UN Doc. CRC/C/15/Add. 122.

UNCESCR (1991), 'General Comment 4', UN Doc. HRI/GEN//Rev.3, 63.

UNCESCR (1999), 'General Comment 12', UN Doc. E/C.12/1999/5.

UNCESCR (1999), 'General Comment 23', UN Doc. HRI/GEN/1/Rev.3, 41.

UNCESCR (2000), 'General Comment 14', UN Doc. E/C.12/2000/4. 